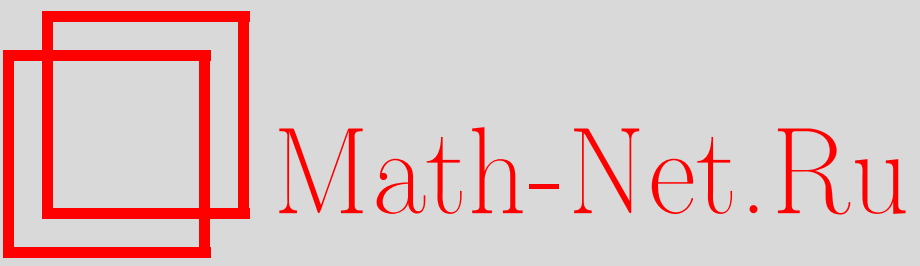

В. П. Радченко, М. Н. Саушкин, К 75-летию со дня рождения Юрия Петровича Самарина, Вестн. Сам. гос. техн. ун-та. Сер. Физ.-мат. науки, 2011, выпуск 4(), 8-12

DOI: https://doi.org/10.14498/vsgtu1036

Использование Общероссийского математического портала Math-Net.Ru подразумевает, что вы прочитали и согласны с пользовательским соглашением

http: //www . mathnet.ru/rus/agreement

Параметры загрузки:

IP : 52.23 .180 .231

26 апреля 2023 г., 14:18:41 


\section{К 75-летию со дня рождения Юрия Петровича Самарина}

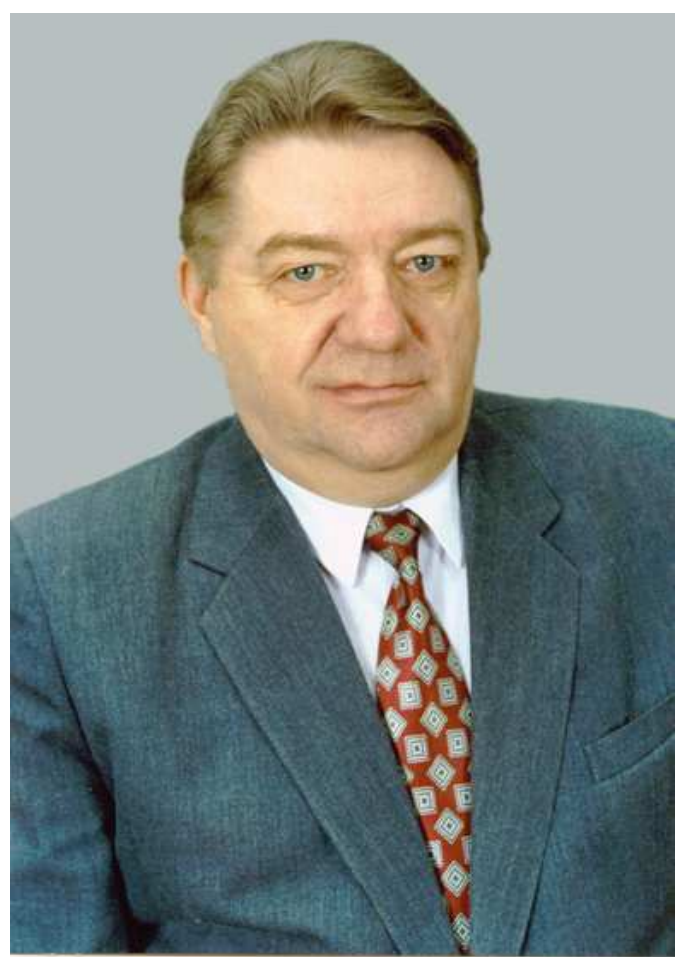

$(18.12 .1936-05.04 .2000)$

18 декабря 2011 г. исполняется 75 лет со дня рождения Юрия Петровича Самарина.

Юрий Петрович Самарин родился в 1936 году в Саратовской области. Его отец работал агрономом, мать была домохозяйкой.

В 1959 году Юрий Петрович с отличием окончил Куйбышевский индустриальный институт по специальности инженер-механик. Затем традиционная для того времени ситуация - два года работы по распределению на заводе «Металлист». Параллельно был соискателем ученой степени кандидата наук в институте. На заводе он от помощника мастера, начавшего с заточки рабочих резцов и сверл, поднялся до заместителя начальника цеха. По его признанию, заводские годы он вспоминал с удовольствием, хотя и было тогда трудно: многочасовые поездки на завод, который находился на окраине города, работа в три смены, учеба, молодая семья.

В 1961 году, сдав кандидатские экзамены, Юрий Петрович был зачислен в аспирантуру индустриального института. Его руководителем был заведующий кафедрой высшей математики Владимир Исаакович Квальвассер, который предложил ему тему в области уравнений математической физики. Не 
имея фундаментального математического образования, Юрий Петрович самостоятельно освоил университетскую программу для механико-математических факультетов, подготовил кандидатскую диссертацию по теме «Краевые задачи математической физики, связанные с колебаниями тел с подвижной границей» и защитил её в 1966 году в Казанском государственном университете.

Жизнь Юрия Петровича Самарина неразрывно связана с Самарским государственным техническим университетом (Куйбышевским политехническим институтом). В 1963 году он пришел на кафедру высшей математики и прошел путь ассистента, старшего преподавателя, доцента, а с 1971 стал заведующим кафедрой, обязанности которого исполнял до конца жизни.

За этот период кафедра стала опорной среди математических кафедр технических вузов области. При непосредственном участии Юрия Петровича в 1993 году через учебно-методическое объединение университетов при факультете вычислительной математики и кибернетики Московского государственного университета в СамГТУ была открыта специальность «Прикладная математика и информатика».

При Юрии Петровиче Самарине на кафедре была открыта аспирантура и докторантура по специальности 01.02.04 «Механика деформируемого твердого тела», а также аспирантура по специальности 05.13.18 «Математическое моделирование, численные методы и комплексы программ». Успешно продолжала действовать ранее открытая аспирантура по специальности 01.01.02 «Дифференциальные уравнения». Подготовка аспирантов по трём этим специальностям продолжается и в настоящее время на кафедре «Прикладная математика и информатика» СамГТУ.

С 1977 года Юрий Петрович Самарин был назначен на должность проректора по научной работе, а с 1985 по 1999 годы он являлся ректором СамГТУ.

Юрий Петрович Самарин - известный деятель в сфере высшего образования и науки. С 1987 по 1999 годы он возглавлял совет ректоров вузов Самарской области.

Хорошо понимая, что сложная, дорогостоящая работа ученых, фундаментальные исследования часто идут впустую, не доходя до производства или доходя подчас уже устаревшими, Юрий Петрович приложил много сил для создания Поволжского отделения Российской инженерной академии (ПО РИА) - квалифицированной структуры для связи производства с наукой, обладающей реальными экономическими возможностями. Поволжское отделение РИА (Самара, Пенза, Ульяновск, Саратов, Волгоград, Астрахань) было организовано в числе первых четырёх. Оно стало научно-техническим учреждением нового типа, затронув и производственную часть. Большие работы велись в области автомобилестроения с АвтоВАЗом, в области энергосбережения с $\mathrm{PAO}$ «Газпром» и многими министерствами (министерством путей сообщения, атомной промышленности и другими). При Юрии Петровиче Самарине Поволжское отделение РИА было одним из лучших в России.

Юрий Петрович Самарин является известным в стране и за рубежом ученым. Им создано научное направление и научная школа по прочности и надежности конструкций, а также теории ползучести материалов и элементов конструкций, которые открыли новые возможности в механике сред, дефор- 
мируемых во времени, и позволили решить ряд актуальных фундаментальных и прикладных задач.

Круг научных интересов Юрия Петровича не ограничивался проблемами реологии. У него имеется значительное число работ, относящихся к вопросам теории надежности и решению задач о разгоне оболочек под действием ударных волн, о прессовании сыпучих сред с наложением вибраций, по уравнениям математической физики, о колебаниях в областях с переменными границами, о непараметрическом выравнивании экспериментальных данных и др.

Юрием Петровичем Самариным опубликовано 8 книг и более 250 работ, некоторые из них - в зарубежных изданиях. Основными являются монографии: «Уравнения состояния материалов со сложными реологическими свойствами» (1979 г.); «Математика для студентов технических вузов» $(1990$ г.); «Ползучесть материалов и конструкций» (1990г.); «Обобщенные модели в теории ползучести конструкций» (1994г.); «System analysis for creep in material and structures» (1996 г.); «Технологическое обеспечение точности фасонных поверхностей при абразивной обработке» (1999г.) и др. Им подготовлены 12 докторов и 24 кандидата наук. Его хорошо знали зарубежные ученые. Он участвовал в нескольких десятках международных форумов, проходивших в США, Германии, Великобритании, Италии, Франции, Греции, Болгарии, Венгрии, Испании и других странах.

Объективным критерием значимости научных исследований Ю. П. Самарина является то, что выдвинутая им в коллективе ученых из Московского государственного университета и Сибирского отделения Российской академии наук научная работа по вопросам прочности была удостоена Государственной премии Российской Федерации, при этом была проведена строгая экспертиза, общественное обсуждение, общественная защита в Институте машиноведения РАН (г. Москва).

Юрий Петрович Самарин награжден орденом Трудового Красного Знамени, медалью «Ветеран труда», Почетной грамотой правительства РФ, двумя медалями ВДНХ. За заслуги в научно-педагогической деятельности он удостоен почетного звания «Заслуженный деятель науки и техники РСФСР» и нагрудного знака «Почетный работник высшего образования России».

В Юрии Петровиче удачно сочетались академическая, фундаментальная подготовка ученого и живой ум гражданина и руководителя.

75-летию со дня рождения Юрия Петровича была посвящена Восьмая всероссийская конференция с международным участием «Математическое моделирование и краевые задачи (ММиКЗ-2011)», которая проводилась Самарским государственным техническим университетом с 15 по 17 сентября 2011 г. при участии Инженерной академии России (Поволжский филиал).

Конференция ММиКЗ-2011 развивает традиции и идеи, заложенные ещё в 1972 году, когда на базе кафедры «Высшая математика» СамГТУ (тогда КПТИ) был создан факультет математических знаний, в рамках которого прошли 18 ежегодных межвузовских конференций. С этого времени началась история проведения периодических математических конференций в СамГТУ, основоположниками которых были профессор Юрий Петрович Самарин и доцент Марк Ефимович Лернер. В 1990 году преемницей этих конференций стала межвузовская научная конференция «Математическое моделирование и краевые задачи», которая проходила ежегодно в течение 13 лет. Бессмен- 
ным организатором и председателем оргкомитета этой конференции до конца своей жизни был ректор СамГТУ профессор Юрий Петрович Самарин. С 2004 года конференция «Математическое моделирование и краевые задачи» приобрела статус всероссийской

В работе конференции принимали участие представители нескольких десятков вузов России (г.г. Москва, Санкт-Петербург, Красноярск, Казань, Воронеж, Новосибирск, Екатеринбург, Челябинск, Чебоксары, Самара, Нальчик, Саранск, Пермь, Ульяновск и др.) и стран ближнего зарубежья (Беларусь, Украина, Узбекистан, Казахстан, Азербайджан), сотрудники ряда промышленных предприятий Самары, Тольятти и других городов России.

Научная программа конференции была посвящена проблемам в области математического моделирования при решении прикладных задач управления, системного анализа, механики и мехатроники; проблемам в области фундаментальных исследований в теории дифференциальных уравнений и краевых задач, а также в области информационных технологий. Как фигура разносторонняя и широкая, Юрий Петрович Самарин имел научные интересы в каждой из перечисленных областей, многие его ученики и в настоящее время развивают эти направления.

Для участия в конференции зарегистрировались 273 человека. По четырём секциям заявлено более 300 докладов, из которых оргкомитетом было отобрано около 180, а по материалам докладов к началу конференции изданы труды в трёх частях, которые участники получили при регистрации.

В первой части трудов опубликованы материалы, в которых отражаются вопросы математического моделирования механических систем со сложными реологическими свойствами материалов; общие вопросы оценки надежности, устойчивости, приспособляемости, разрушения и динамического поведения механических систем. Актуально выглядят работы, посвящённые учёту третьей стадии ползучести и построению критериев разрушения материалов, накоплению повреждённости и других факторов, связанных с процессом ползучести элементов конструкций и материалов.

Ряд работ посвящен развитию структурных моделей неупругого деформирования и разрушения сплошной среды, позволяющих более полно понять механизмы деформирования и разрушения на микроуровне и описать ряд эффектов, которые с феноменологических позиций адекватно описать не удаётся в силу ограниченности (или отсутствия) соответствующих экспериментальных данных. Не менее интересны с теоретической и практической точек зрения работы, в которых проводится теоретическое и экспериментальное моделирование и исследование стохастических полей неупругой деформации для материалов и элементов конструкций с учётом разрушения, а также работы, посвященные описанию пластической деформации, исследованиям закритического деформирования материалов, построению критериев разрушения материалов в условиях пластичности. Часть докладов этой секции посвящена сугубо прикладным вопросам исследования поведения конкретных конструктивных элементов, а также обеспечению требуемой надёжности в технологических процессах.

Во многих работах достаточно широко представляются вопросы численной реализации соответствующих краевых задач и оптимального использования вычислительной техники при их решении. 
В материалах второй и четвёртой секций отражаются вопросы оптимизации и управления сложными системами и технологическими процессами, приводятся постановки задач для динамических систем с распределёнными параметрами и методы их решения. Рассматривается ряд прикладных задач в различных областях научных исследований, анализируются их математические модели. Часть работ посвящена современным компьютерным технологиям.

В третьей части трудов конференции ряд публикаций посвящен классическим краевым задачам для уравнений смешанного типа. По характеру докладов на конференции можно судить о неослабевающем интересе специалистов по краевым задачам для дифференциальных уравнений с частными производными и интегральным уравнениям к нелокальным краевым задачам для уравнений гиперболического, параболического и смешанного типов. Этот интерес в немалой степени обусловлен их приложениями в прикладных задачах. Часть публикаций посвящена постановкам и методам решения нелокальных краевых задач с частными производными. K числу таких уравнений, помимо нагруженных уравнений, относятся уравнения с дробными и континуальными производными; уравнения, содержащие инволютивное отклонение (карлемановский сдвиг) в аргументах искомых функций, и дифференциальные уравнения с запаздывающими аргументами. Следующее направление исследований - интегральные уравнения и специальные функции - представлено в трудах конференции, в первую очередь, работами, связанными с интегральными уравнениями со специальными функциями в ядрах, методами решения интегральных уравнений II и III рода, а также интегро-дифференциальных уравнений.

На торжественном официальном закрытии конференции были подведены итоги работы секций, за лучшие доклады молодым учёным были вручены дипломы (12 призеров, по 3 в каждой секции). Подводя итоги конференции, её участники отметили не только высокий организаторский уровень проведения данного мероприятия, но и высокий уровень научных работ, их новизну, а также большую практическую значимость представленных докладов.

Участники отметили, что конференция служит интересам науки и практики, дает новый импульс взаимодействию между теоретиками и практиками и позволяет в дальнейшем найти достойное применение представленным на обсуждение научным результатам. Было отмечено, что конференции такого уровня позволяют обмениваться современной научной информацией, служат укреплению научных контактов и координации взаимодействия между различными научно-исследовательскими коллективами в вопросах приложений математических моделей. Все это активно пропагандировалось и реализовывалось и Юрием Петровичем Самариным, да и было фактически смыслом всей его жизни в науке.

Заведующий кафедрой «Прикладная математика и информатика» СамГТУ д.ф.-м.н., профессор В. П. Радченко, доцент кафедры «Прикладная математика и информатика» СамГТУ к.ф.-м.н., дочент М. Н. Саушкин 